Article

\title{
Single Cell Mass Cytometry Revealed the Immunomodulatory Effect of Cisplatin Via Downregulation of Splenic CD44+, IL-17A+ MDSCs and Promotion of Circulating IFN- $\gamma+$ Myeloid Cells in the 4T1 Metastatic Breast Cancer Model
}

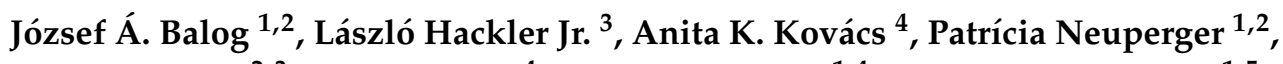 \\ Róbert Alföldi ${ }^{2,3}$, Lajos I. Nagy ${ }^{4}$, László G. Puskás ${ }^{1,4}$ and Gábor J. Szebeni ${ }^{1,5, *}$ \\ 1 Laboratory of Functional Genomics, Biological Research Centre, Temesvári krt. 62, H6726 Szeged, Hungary; \\ balog.jozsef@brc.hu (J.Á.B.); neuperger.patricia@brc.hu (P.N.); laszlo@avidinbiotech.com (L.G.P.) \\ 2 PhD School in Biology, University of Szeged, H6726 Szeged, Hungary; r.alfoldi@astridbio.com \\ 3 AstridBio Technologies Ltd., Also kikötő sor 11/D, H6726 Szeged, Hungary; laszlo.hackler@astridbio.com \\ 4 Avidin Ltd., Also kikötő sor 11/D, H6726 Szeged, Hungary; a.kovacs@avidinbiotech.com (A.K.K.); \\ l.nagy@avidinbiotech.com (L.I.N.) \\ 5 Department of Physiology, Anatomy and Neuroscience, Faculty of Science and Informatics, \\ University of Szeged, Közép fasor 52, H6726 Szeged, Hungary \\ * Correspondence: szebeni.gabor@brc.hu
}

Received: 30 November 2019; Accepted: 24 December 2019; Published: 25 December 2019

\begin{abstract}
The treatment of metastatic breast cancer remained a challenge despite the recent breakthrough in the immunotherapy regimens. Here, we addressed the multidimensional immunophenotyping of 4T1 metastatic breast cancer by the state-of-the-art single cell mass cytometry (CyTOF). We determined the dose and time dependent cytotoxicity of cisplatin on $4 \mathrm{~T} 1$ cells by the $x$ Celligence real-time electronic sensing assay. Cisplatin treatment reduced tumor growth, number of lung metastasis, and the splenomegaly of $4 \mathrm{~T} 1$ tumor bearing mice. We showed that cisplatin inhibited the tumor stroma formation, the polarization of carcinoma-associated fibroblasts by the diminished proteolytic activity of fibroblast activating protein. The CyTOF analysis revealed the emergence of $\mathrm{CD} 11 \mathrm{~b}+/ \mathrm{Gr}-1+/ \mathrm{CD} 44+$ or CD11b+/Gr-1+/IL-17A+ myeloid-derived suppressor cells (MDSCs) and the absence of B220+ or CD62L+ B-cells, the CD62L+/CD4+ and CD62L+/CD8+ T-cells in the spleen of advanced cancer. We could show the immunomodulatory effect of cisplatin via the suppression of splenic MDSCs and via the promotion of peripheral IFN- $\gamma+$ myeloid cells. Our data could support the use of low dose chemotherapy with cisplatin as an immunomodulatory agent for metastatic triple negative breast cancer.
\end{abstract}

Keywords: single cell mass cytometry; metastatic breast cancer; myeloid-derived suppressor cells; immunophenotyping

\section{Introduction}

The role of the tumor microenvironment, the interaction of cancer cells with the extracellular matrix, endothelial cells, cancer-associated fibroblasts, and leukocytes in the tumor stroma have been increasingly considered as a milestone in cancer development, especially in the last decade [1,2]. The deeper understanding of the disturbances in the regulation and activation of the immune system in cancer resulted in the advancement of anti-cancer therapies, such as the immune checkpoint blockade 
(ICB) [3]. However, the treatment of poorly immunogenic and metastasizing tumors remained a challenge.

Here, we focus on female breast cancer since it is the most frequent cancer in women and still the deadliest cancer type between the ages of 20-49 years old in contrast to the achievements in early diagnostics and therapeutics $[4,5]$. In our work the murine mammary carcinoma of the $\mathrm{BALB} / \mathrm{c}$ mice, the syngeneic $4 \mathrm{~T} 1$ was studied [6]. The $4 \mathrm{~T} 1$ model is among the few murine triple negative breast cancer (TNBC) models that spontaneously metastasize to sites affected in human breast cancer (e.g., lung) in an immunocompetent host [7]. Orthotopic transplantation of $4 \mathrm{~T} 1$ cells offers a relevant tumor model to study efficacy of drug candidates or immune therapy regimens [8]. Previously, we showed the tumor promoting effect of mesenchymal stem cell (cancer associated fibroblast)-derived galectin-1 in the 4T1 model [9], and later on we screened an anti-cancer compound library of imidazo[1-2-b]pyrazole-7-carboxamides in both two- and three-dimensional cell cultures of $4 \mathrm{~T} 1$ cells $[10,11]$.

We have previously reviewed how cancer-related chronic inflammation can lead to the generation of immature myeloid-derived suppressor cells (MDSCs) and to the alternative polarization of tumor-associated macrophages (TAMs) [12], which manifests autonomously in the 4T1 breast cancer model $[13,14]$. It has been shown that the granulocytic MDSCs support metastases by suppressing CD8+ T-cells in the 4T1 breast tumor model [15]. It was also recently shown that 4T1 cells shape immune responses with an increase of splenic CD11b+ cells to promote cancer growth in an Shb (SRC homology-2 domain protein B) dependent manner [16]. The 4T1 tumor cells are poorly immunogenic and refractory to immune therapies, although the combination of anti-PD-1, anti-CTLA-4 ICB with epigenetic modulators could have a therapeutic benefit curing more than $80 \%$ of $4 \mathrm{~T} 1$ tumor bearing mice via eliminating MDSCs [17]. We have previously reviewed strategies targeting these myeloid-derived suppressors cells or tumor associated macrophages to combat cancer [18]. Here, the traditional chemotherapeutic agent, the DNA crosslinker cisplatin was used, since cisplatin and platinum-based chemoterapeutics are in the clinical routine as first line treatment option in several cancers such as lung, bladder, ovarian and metastatic breast cancer [19]. Recent studies have shown the immune induction by cisplatin in human TNBC (the TONIC trial NCT02499367) [20], or in murine carcinoma models showing enhanced sensitivity to ICB therapy in combination with cisplatin treatment but these studies did not deal with immunophenotyping of the myeloid compartment [21,22]. The beneficial effect of cisplatin on the course of 4T1 tumor development was shown recently in combination with metformin or bromelain $[23,24]$, but these studies also did not address the characterization of the immunophenotype.

To the best of our knowledge our study is the first, where mass cytometry, a multidimensional single cell technology with computational data analysis was carried out in order to reveal the immunophenotype of 4T1 murine triple negative breast carcinoma and the effect of cisplatin treatment on the splenic and circulating immune compartments.

\section{Results}

\subsection{Real-Time Monitoring of $4 T 1$ Cell Viability Hampered by Cisplatin}

Determination of the half maximal inhibitory concentration, the $\mathrm{IC}_{50}$ of cisplatin on $4 \mathrm{~T} 1$ cells was carried out using the real-time electronic sensing xCelligence system [25]. The detected impedance is proportional with the percentage of adhered living cells to the gold coated plate and the decline in the normalized cell index corresponds to hampered cell viability (Figure 1). The effect of cisplatin on viability was followed for $120 \mathrm{~h}$ after treatment in every $15 \mathrm{~min}$ (former studies reported endpoint assays with cisplatin on $4 \mathrm{~T} 1$ cells). The $\mathrm{IC}_{50}$ values were as follows $36.74 \mu \mathrm{M}$ at $24 \mathrm{~h}, 7.608 \mu \mathrm{M}$ at $48 \mathrm{~h}$, $6.962 \mu \mathrm{M}$ at $72 \mathrm{~h}, 4.128 \mu \mathrm{M}$ at $96 \mathrm{~h}$, and $3.995 \mu \mathrm{M}$ at $120 \mathrm{~h}$ (Figure S1). 


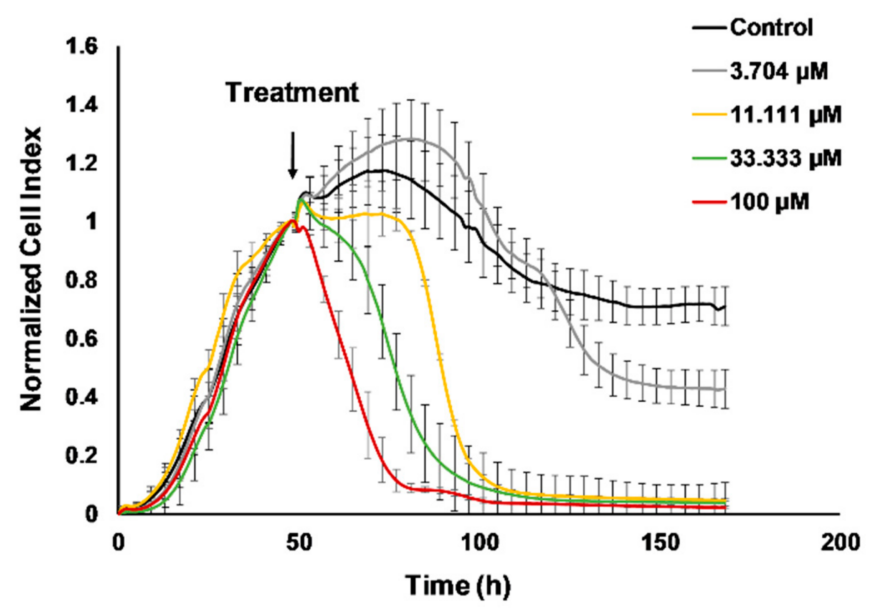

Figure 1. Real-time monitoring of $4 \mathrm{~T} 1$ cell viability hampered by cisplatin. The $4 \mathrm{~T} 1$ cells were seeded and the baseline impedance was recorded for $48 \mathrm{~h}$. After that $48 \mathrm{~h}$ culturing treatment with $11.111 \mu \mathrm{M}$, $33.333 \mu \mathrm{M}$, or $100 \mu \mathrm{M}$ cisplatin reduced viability of $4 \mathrm{~T} 1$ cells on a time and dose dependent manner. The corresponding dose-response curves with the half maximal inhibitory concentration $\left(\mathrm{IC}_{50}\right)$ values can be found in Figure S1.

2.2. Cisplatin Treatment Reduced $4 T 1$ Tumor Growth, the Number of Lung Metastatic Nodules and the Weight of the Spleen

The syngeneic BALB/c mice were orthotopically transplanted with $4 \mathrm{~T} 1$ breast cancer cells in order to establish the animal model for the addressed immunophenotyping. Tumor growth was monitored daily. All mice treated with cisplatin showed markedly reduced tumor growth compared to untreated 4T1 tumor bearing mice represented by the average tumor volume of $102 \mathrm{~mm}^{3}$ versus (vs.) $1481 \mathrm{~mm}^{3}$ on the 21st day (Figure 2A). On the 23rd day mice were euthanized for immunophenotyping and the weight of the tumors (Figure 2B), the number of metastatic nodules (macrometastasis) on the lungs (Figure 2C), and the weight of the spleens were measured (Figure 2D).

The average weight of the tumors was reduced by almost $90 \%$ due to cisplatin treatment, namely $426.4 \pm 110.1 \mathrm{mg}$ (mean \pm SEM) in the cisplatin treated $4 \mathrm{~T} 1$ tumorous mice vs. $3087 \pm 356 \mathrm{mg}$ in the untreated 4T1 tumor bearing mice (Figure 2B). The development of metastatic nodules on the surface of the lungs were also inhibited by cisplatin, the average number of lung macrometastasis were as follows: $0.42 \pm 0.23$ in cisplatin treated vs. $3.25 \pm 0.524$ in untreated $4 \mathrm{~T} 1$ tumorous mice (Figure 2C). Splenomegaly is one sign of myeloid cell expansion due to cancer related inflammation in tumor bearing hosts [26]. Cisplatin treatment suppressed the enlargement of the spleen as spleen weights were $143.04 \pm 19.25 \mathrm{mg}, 843.59 \pm 38.69 \mathrm{mg}, 123.91 \pm 26.08 \mathrm{mg}$, in the naive, $4 \mathrm{~T} 1$ tumor bearing and cisplatin treated 4T1 tumor bearing mice, respectively (Figure 2D). 
A

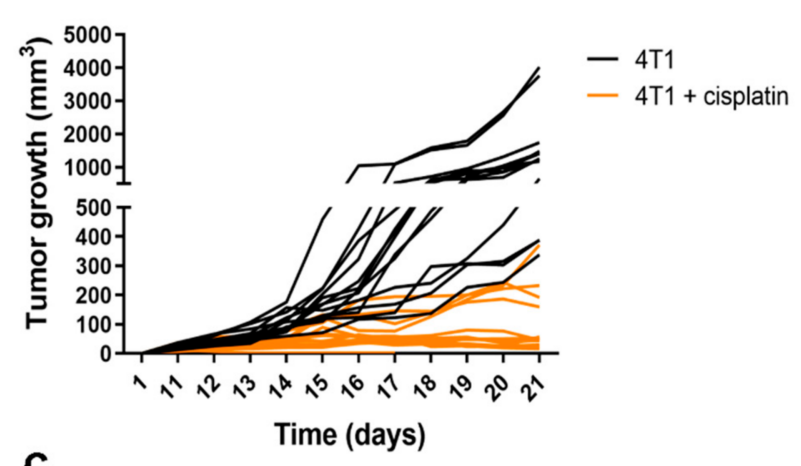

C

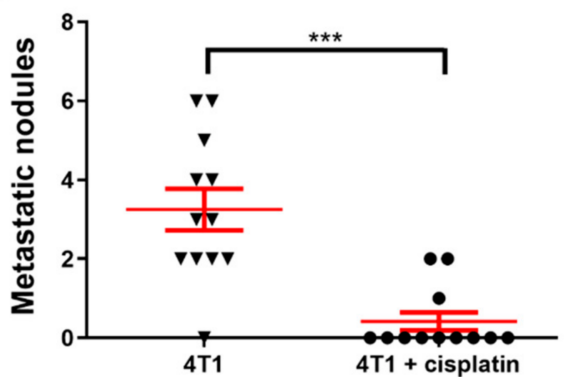

B

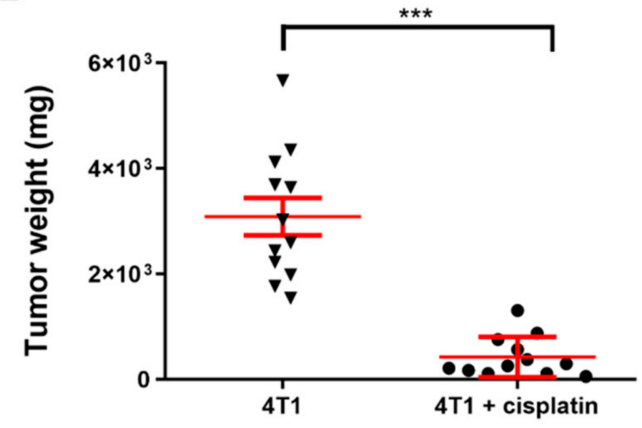

D

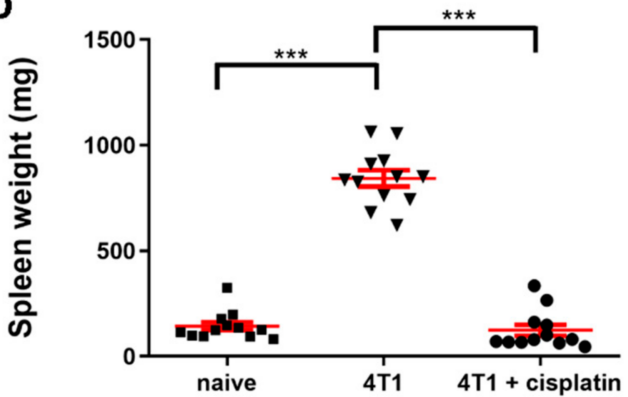

Figure 2. Cisplatin treatment reduced $4 \mathrm{~T} 1$ tumor growth, the number of lung metastatic nodules and the weight of the spleen. The $4 \mathrm{~T} 1$ cells $\left(1.2 \times 10^{5}\right)$ were transplanted by the injection into the mammary fat pad of BALB/c mice $(n=12)$. Tumor growth was monitored daily $(\mathbf{A})$. On the 23 rd day mice were euthanized and the weight of the tumors (B), the number of metastatic nodules on the lungs (C), and the weight of the spleens were measured (D). Individual values and arithmetic mean values of the samples \pm standard error of the mean (SEM) are plotted, statistical significance was set to ${ }^{* * *} p<0.001$.

\subsection{Cisplatin Reduced the Activity of Fibroblast Activator Protein (FAP)}

The increased activity of the prolyl endopeptidase FAP enzyme is a hallmark of the tumor stroma, because of the accumulation and activation of cancer associated fibroblasts (CAFs). The FAP protease activity either membrane bound on CAFs or solubilized, is proportional with the malignancy [27]. The activity of FAP enzyme was investigated, because it has been reported that the accumulation of CAFs in the tumor stroma and their expression of FAP contributes to the chemoresistance to cisplatin in carcinomas [28,29]. We have synthetized a peptide substrate (Fmoc-Gly-Pro-Cysteic acid-Ile-Gly- $\mathrm{NH}_{2}$, Figure S2) in order to measure FAP activity in the plasma of naive, 4T1 tumor bearing and cisplatin treated $4 \mathrm{~T} 1$ tumorous mice (Figure 3). 


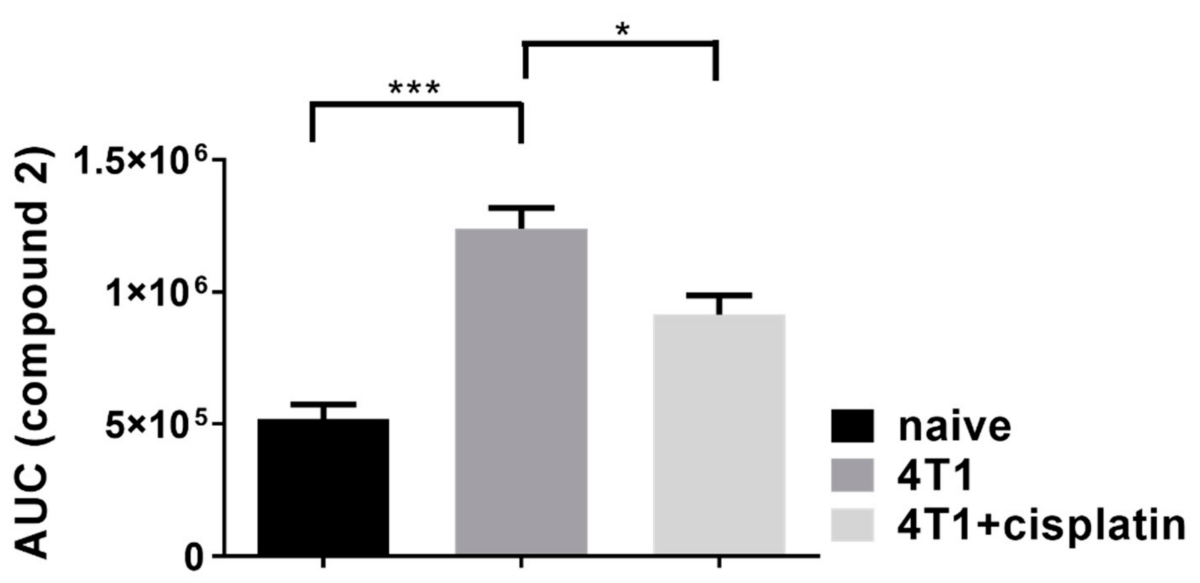

Figure 3. The proteolytic activity of the fibroblast activator protein (FAP) increased by the formation of breast cancer, and was significantly decreased by cisplatin treatment. Area under the curve (AUC) values from high pressure liquid chromatography (HPLC) analysis of the peptide digestion product 2 (Figure S2) were plotted. The results are shown as arithmetic mean values of the samples \pm standard error of the mean (SEM), statistical significance was set to ${ }^{* *} p<0.001,{ }^{*} p<0.05$.

FAP enzyme activity quantification was based on a direct measurement of a digested peptide product with high pressure liquid chromatography (HPLC) (Figure S2). Fmoc-GP-Cox- was synthesized (Avidin Ltd.) and used as a substrate, where "Cox" denotes for oxydized cysteine, namely, cysteic acid. We used oxidized cysteine amino acid at position 3 in the peptide substrate of FAP, instead of unmodified cysteine. In a preliminary experiment, we confirmed that the peptide with the oxidized cysteine residue was the same or better substrate of FAP. Moreover, our improved peptide substrate is more water soluble and after FAP digestion the dipeptide product (Fmoc-GP) could be better separated from the intact substrate during HPLC analysis, then the unmodified version, enabling us more accurate and sensitive quantification. We could detect FAP activity in the plasma of naive, $4 \mathrm{~T} 1$ tumor bearing and cisplatin treated $4 \mathrm{~T} 1$ tumorous animals with the following average AUC ( \pm SEM) values from HPLC analysis: $518.5 \pm 55.5 \times 103,1240.2 \pm 77.9 \times 103,914.9 \pm 71.7 \times 103$, respectively (Figure 3).

\subsection{Single Cell Mass Cytometry (SCMC) Revealed the Immunophenotype of Breast Cancer Bearing Mice}

\subsubsection{Cisplatin Restored the Splenic Immunophenotype of 4T1 Tumor Bearing Mice}

In order to investigate the immunophenotype of $4 \mathrm{~T} 1$ breast cancer single cell mass cytometry was performed with 24 antibodies in one single tube (see Table 1 in Section 4.5). We intended to monitor the draining lymph nodes, bone marrow, spleen, and blood of the naive, 4T1 tumor bearing, and cisplatin treated $4 \mathrm{~T} 1$ tumorous animals. However, the orthotopic injection of $4 \mathrm{~T} 1$ cells into the mammary fat pad resulted in the outgrowth of the tumor mass in co-junction with the draining cervical and axillary lymph nodes making them undetectable. Bone marrow staining showed homogenous immature cells (little CD11+ Gr1+ elevation in tumor bearing hosts) excluding these samples from further analysis. Our attention turned toward the spleen since it has been published in the seminal paper of Bronte et al. that tolerance to tumor antigens develops in the spleen [30]. During the SCMC analysis of the spleen CD45+ living singlets were gated and on these leukocytes the unsupervised and multidimensional visualization of stochastic neighbor embedding (viSNE) analysis was performed delineating the separate clouds of different main immune subsets (Figure 4) [31]. 
Table 1. The list of the antibodies used for mass cytometry.

\begin{tabular}{|c|c|c|}
\hline Target & Clone & Metal Tag \\
\hline Gr-1 (Ly6C/Ly6G) & RB6-8C5 & 141_Pr \\
\hline CD11c & N418 & 142_Nd \\
\hline CD69 & $\mathrm{H} 1.2 \mathrm{~F} 3$ & 145_Nd \\
\hline CD45 & 30-F11 & 147_Sm \\
\hline CD11b & M1/70 & 148_Nd \\
\hline CD19 & 6D5 & 149_Sm \\
\hline CD25 & $3 C 7$ & 151_Eu \\
\hline CD3e & $145-2 \mathrm{C} 11$ & 152_Sm \\
\hline TER-119 & TER119 & 154_Sm \\
\hline CD62L & MEL-14 & 160_Gd \\
\hline CD8a & $53-6.7$ & 168_Er \\
\hline $\mathrm{TCR} \beta$ & H57-597 & 169_Tm \\
\hline NK1.1 & PK136 & 170_Er \\
\hline CD44 & IM7 & $171 \_\mathrm{Yb}$ \\
\hline CD4 & RM4-5 & $172 \_\mathrm{Yb}$ \\
\hline B220 & Ra3-6B2 & 176_Yb \\
\hline IFN- $\gamma$ & XMG1.2 & 165_Ho \\
\hline IL-2 & JES6-5H4 & 144_Nd \\
\hline IL-4 & 11B11 & 166_Er \\
\hline IL-5 & TRFK5 & 143_Nd \\
\hline IL-6 & MP5-20F3 & 167_Er \\
\hline IL-10 & JES5-16E3 & 158_Gd \\
\hline IL-17A & TC11-18H10.1 & 174_Yb \\
\hline $\mathrm{TNF} \alpha$ & MP6-ХT22 & 162_Dy \\
\hline
\end{tabular}

Both the CD4+ and CD8+ T-cells were almost completely absent and the percentage of CD19+ B-cells decreased from $50 \%$ to $10 \%$ of CD45+ living singlets in the spleen of the $4 \mathrm{~T} 1$ tumor bearing mice (Figure $4 \mathrm{D}, \mathrm{E}$ ). The percentage of the myeloid CD11b+ cells increased from $10 \%$ to $80 \%$ at the expense of lymphoid subsets due to breast cancer development (Figure 4D,E). Cisplatin treatment of $4 \mathrm{~T} 1$ tumorous mice normalized the splenic immunophenotype similar to naive mice with $25 \% \mathrm{CD} 4+$, 10\% CD8+ T-cells, 40\% CD19+ B-cells, and 20\% CD11b+ cells (Figure 4F). 
A
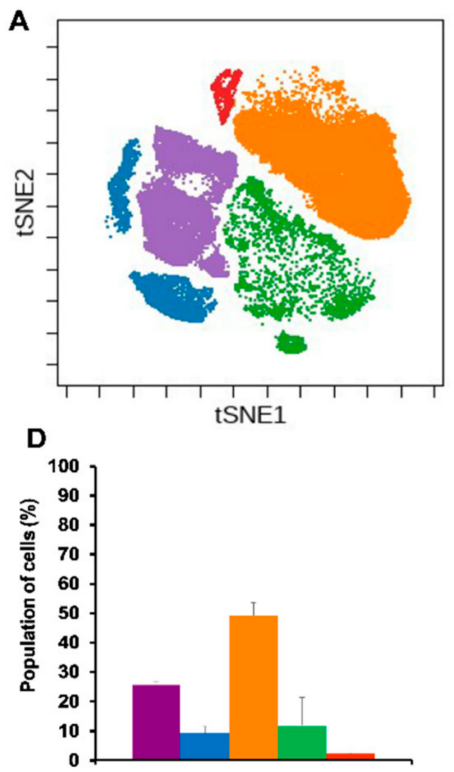

B

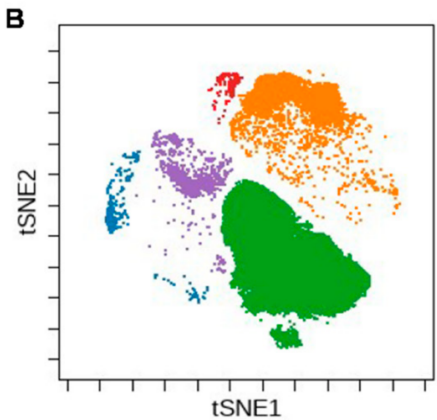

$\mathrm{E}$

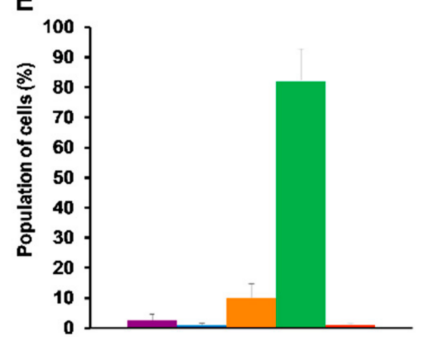

c
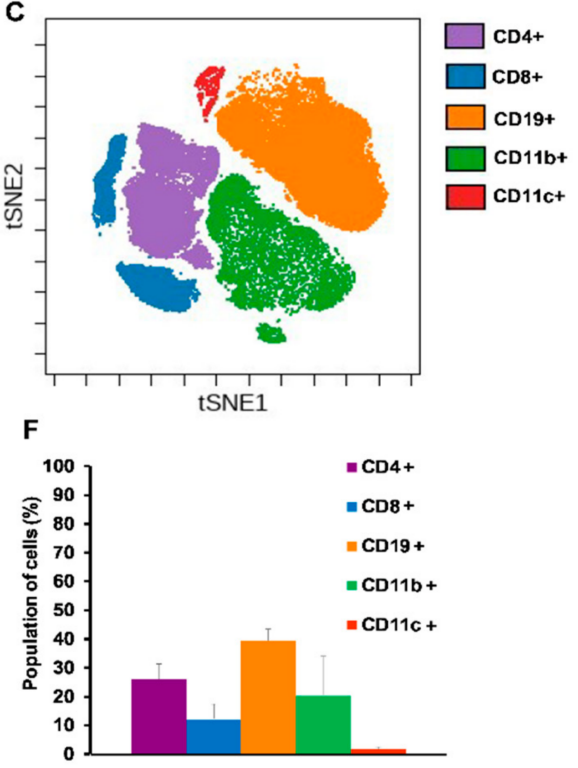

Figure 4. Single cell mass cytometric immunophenotyping showed the accumulation of CD11b+ myeloid cells in 4T1 tumor bearing animals at the expense of lymphoid subsets which was reverted by cisplatin treatment. The visualization of stochastic neighbor embedding (viSNE) analysis was run on the (A) naive, (B) 4T1 tumor bearing, and (C) cisplatin treated 4T1 tumorous animals within the CD45+ living singlets. Quantitative analysis of the main lymphoid subsets: CD4+ T-cells = lilac, $\mathrm{CD} 8+\mathrm{T}$-cells $=$ blue, CD19+ B-cells $=$ orange and the myeloid CD11b $+=$ green, CD11c $+=$ red subsets were performed in the spleen of (D) naive, (E) 4T1 tumor bearing, and (F) cisplatin treated 4T1 tumorous mice within the CD45+ living singlets. Representative viSNE plots and column bars are shown from the pooled samples of 6 mice per group. Data are shown as arithmetic means on the column bars \pm SEM. Pairwise comparison of the emergence of CD11b+ population in (E) vs. (D) and its decrease by cisplatin treatment (F) vs. (E) has statistical significance at $p<0.001$.

The expression intensity of certain proteins within the viSNE plots of main subsets showed dramatic changes (Figure 5). The expression pattern of Gr-1+ (Ly6C/Ly6G), CD44+, and IL-17A+ cells within the cloud of $\mathrm{CD} 11 \mathrm{~b}+$ myeloid cells were uniquely high in the spleen of $4 \mathrm{~T} 1$ breast cancer bearing mice (Figure 5) in accordance with the splenomegaly shown in Figure 2D. On the contrary, the B220 and CD62L markers within the cloud of CD19+ B-cells, and the CD62L within the cloud of CD4+ and CD8+ T-cells also were highly reduced in the spleen of 4T1 tumorous mice (Figure 5). Cisplatin treatment reverted the immunophenotype of both splenic CD11b+ myeloid (Gr-1+, CD44+ and IL-17A+) cells and lymphoid (B220+/CD19+, CD62L+/CD19+, CD62L+/CD4+, CD62L+/CD8+ T-cells) cells similar to naive mice (Figure 5). 

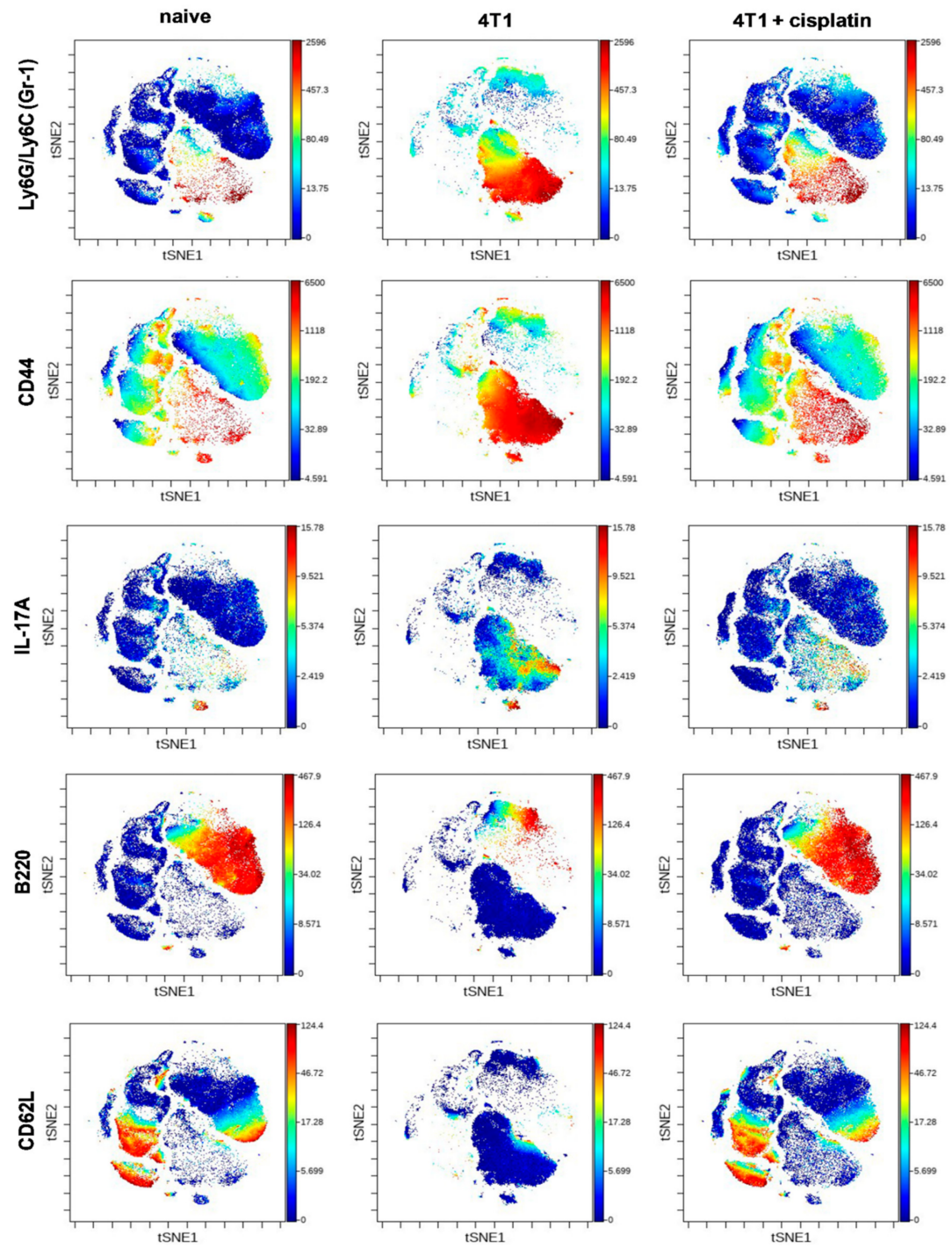

Figure 5. The viSNE plots illustrate the expression intensity of Gr-1, CD44, IL-17A, B220, CD62L markers within the clouds of main subsets defined in Figure 4 in the splenic samples of naive, $4 \mathrm{~T} 1$ tumor bearing, and cisplatin treated 4T1 tumorous mice. The coloration is proportional to the expression intensity (blue $=$ low, red $=$ high). The list of the antibodies can be found in Table 1 in Section 4.5. Representative viSNE plots are shown from the pooled samples of 6 mice per group. The markers of the panel which were not detected or did not show differential expression are not shown.

Quantitation of the populations with characteristic protein expression was performed by manual gating within the CD45+ living singlets of splenocytes (Figure S3). The trajectories on the radar plots delineate the characteristic marker profile of splenocytes of naive, 4T1 tumor bearing, and cisplatin treated tumorous mice (Figure 6). 
A

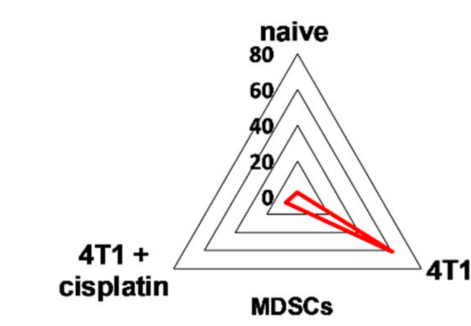

D

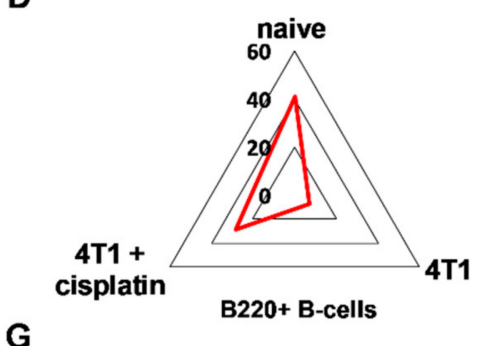

G

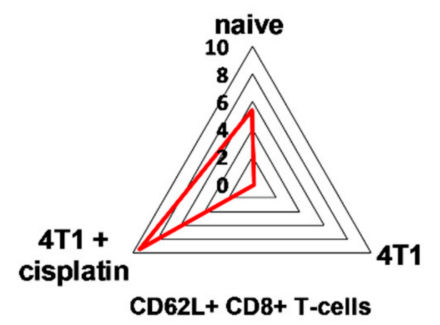

B

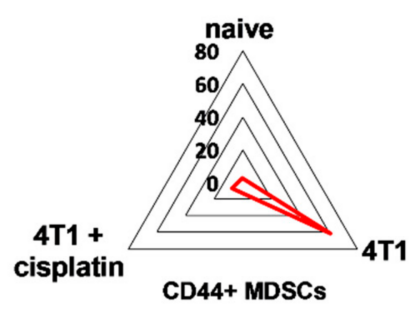

E

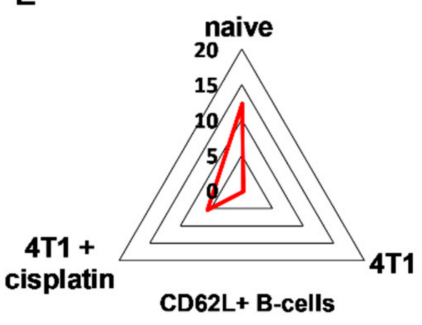

C

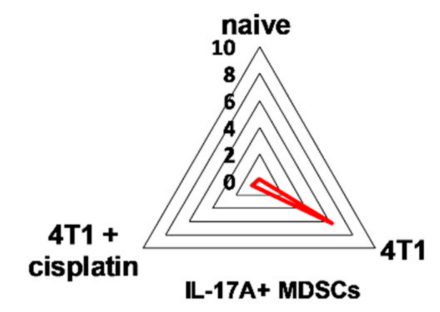

$\mathbf{F}$

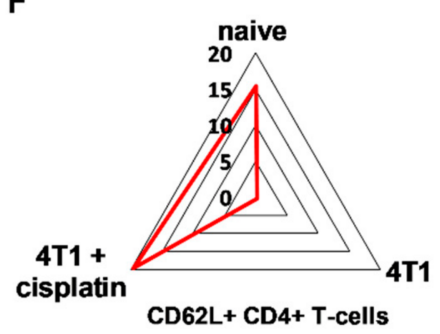

Figure 6. The trajectories on the radar plots delineate the characteristic marker profile of splenocytes in naive, 4T1 tumor bearing, and cisplatin treated tumorous mice. The accumulation of splenic (A) CD11b+/Gr-1+ MDSCs, (B) CD44+, and in a smaller extent (C) IL-17A+ MDSCs is a characteristic of $4 \mathrm{T1}$ breast cancer. Cisplatin restores the percentage of (D) B220+ and (E) CD62L+ B-cells, (F) CD62L+ CD4+ and (G) CD8+ T-cells. The percentage of the given populations is demonstrated on the radar plots within the $\mathrm{CD} 45+$ living singlets determined by manual gating in Cytobank. The gating hierarchy is explained in the text and in Figure S3. The markers of the panel which were not detected or did not show differential expression are not shown. Representative radar plots are shown from the pooled samples of 6 mice per group as described in Section 4.5.

MDSCs were defined as CD45+/CD3-/CD11+/Gr1+ cells and further evaluated for CD44 and IL-17A staining. These MDSCs, CD44+ MDSCs and IL-17A+ MDSCs represented exclusively $60 \%$, $60 \%$ and $6 \%$ of CD45+ living singlets in the spleen of $4 \mathrm{~T} 1$ tumorous mice, respectively. The B-cell marker B220 (except regulatory B-cells, germinal center B-cells, some plasma cells, and certain memory B-cells [32-34]) on CD45+/CD3-/CD19+ B-cells was $40 \%$ in the naive, 30\% in the cisplatin treated, while only $6 \%$ in the untreated $4 \mathrm{~T} 1$ tumorous mice. The homing receptor L-selectin, CD62L was almost absent $(0.2 \%)$ on the splenic B-cells of $4 \mathrm{~T} 1$ tumorous mice but it was restored upon cisplatin treatment to $5.5 \%$ (naive mice $12.5 \%$ ). The CD45+/CD3+/TCR $\beta+/ C D 4+$ and CD45+/CD3+/TCR $\beta+/ C D 8+$ T-cells expressed CD62L $15 \%$ vs. $20 \%$ and $6 \%$ vs. $10 \%$ in the splenocytes of naive and cisplatin treated $4 \mathrm{~T} 1$ bearing mice, respectively. Sunburst charts represent the immunocomposition of main subsets of the spleens detected by single cell mass cytometry in Figure S4A and FlowSOM (Flow data using Self-Organizing Map, [35]) analysis demonstrates the identified clusters, minimum spanning trees (MSTs) of splenic subsets in Figure S5. 
2.4.2. Cisplatin Could not Completely Restore the Peripheral Immunophenotye of 4T1 Tumor Bearing mice but Increased IFN- $\gamma$ Production of Myeloid Cells

Immunophenotype of the blood in breast cancer can reflect the state of the peripheral tolerance associated with cancer-related inflammation or the activation of anti-tumor effector cellular responses [36]. The viSNE plots of the main subsets in blood samples show the absence of peripheral $\mathrm{CD} 4+, \mathrm{CD} 8+\mathrm{T}-$, and B-cells and the emergence of CD11b + cells as a sign of advanced cancer compared to naive blood (Figure 7A,B). Cisplatin treatment at least partially normalized the immunocomposition of the blood of 4T1 tumorous mice (Figure 7C).

A
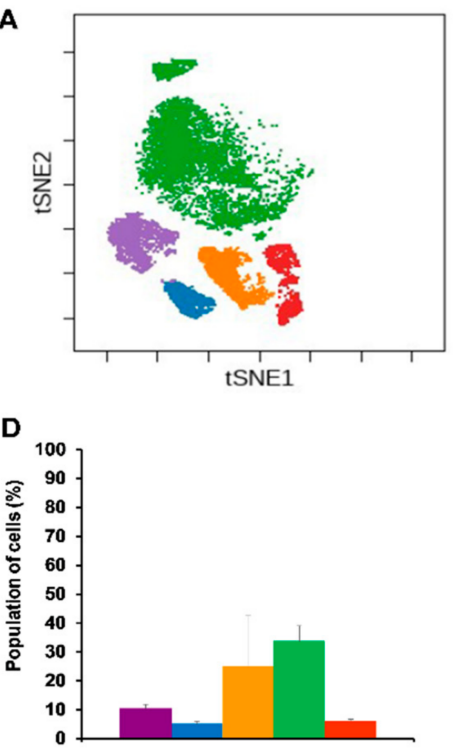

B

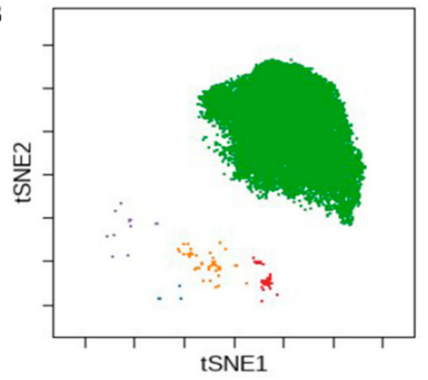

E

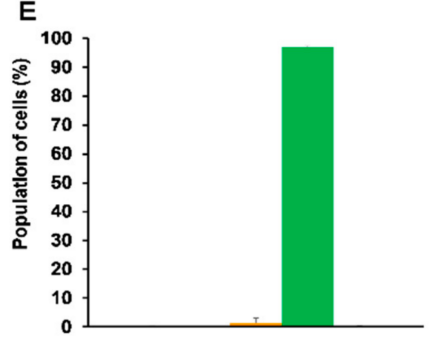

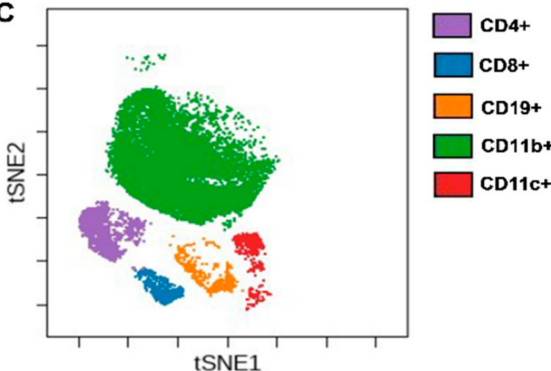

F

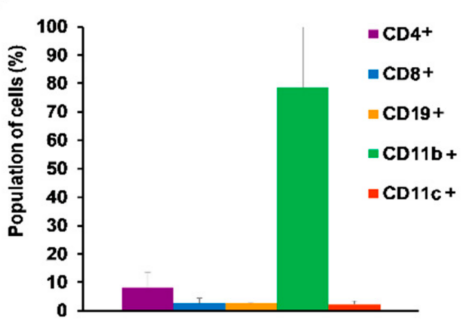

Figure 7. Immunophenotyping of blood showed dramatic expansion of CD11b+ cells in advanced cancer. The viSNE analysis was run on the (A) naive, (B) 4 T1 tumor bearing, and (C) cisplatin treated 4T1 tumorous animals within the CD45+ living singlets. Quantitative analysis of the main lymphoid subsets: CD4+ T-cells = lilac, CD8+ T-cells $=$ blue, CD19+ B-cells $=$ orange and the myeloid CD11b $+=$ green, CD11 $+=$ red subsets was performed in the blood of (D) naive, (E) 4T1 tumor bearing, and (F) cisplatin treated 4T1 tumorous mice within the CD45+ living singlets. Representative viSNE plots and column bars are shown from the pooled samples of 6 mice per group. Data are shown as arithmetic means on the column bars \pm SEM. Pairwise comparison of the emergence of CD11b+ population in (E) vs. (D) has significance at $p<0.001$.

The percentage of CD11b+ cells of $4 \mathrm{~T} 1$ tumor bearing mice due to advanced cancer-related myeloid expansion represented around 97\% (Figure 7E) in contrast to naive mice with 35\% CD11b+ cells (Figure 7D) of CD45+ living singlets in the blood. The treatment of 4T1 breast cancerous mice with cisplatin could not suppress the emergence of CD11b+ cells significantly with an average of 85\% CD11b+ cells (Figure 7F). Myeloid expansion led almost to the absence of circulating T- and B-lymphocytes in advanced cancer (Figure 7E). Cisplatin treatment at least partially restored the percentage of these CD4+, CD8+ T- and CD19+ B-lymphocytes with an average 8.1\% vs. 10.5\%, $2.6 \%$ vs. $5.1 \%, 2.7 \%$ vs. $24.8 \%$ in naive mice, respectively (Figure $7 \mathrm{D}, \mathrm{F}$ ).

The differential expression intensity of the Gr-1, CD44, IFN- $\gamma$ markers on blood-derived leukocytes was plotted on the viSNE graphs (Figure 8). Interestingly, the highest expression protein pattern of Gr-1+/CD44+ (Gr-1+ bright/CD44+ bright $)$ within the CD11b+ subset was associated with early cancer disease in the blood of cisplatin treated $4 \mathrm{~T} 1$ tumorous mice. The Gr-1+ $\operatorname{dim} / \mathrm{CD} 44+\operatorname{dim}$ immature myeloid cells have been reported to suppress T-cells and IFN- $\gamma$ production $[37,38]$, the dim expression intensity of these markers was characteristic to $4 \mathrm{~T} 1$ tumor bearing mice (Figure 8). In line with 
this, the smaller population of IFN- $\gamma$ producing myeloid cells appeared within the CD11 subtype by cisplatin treatment which was completely absent in the advanced cancer (Figure 8).
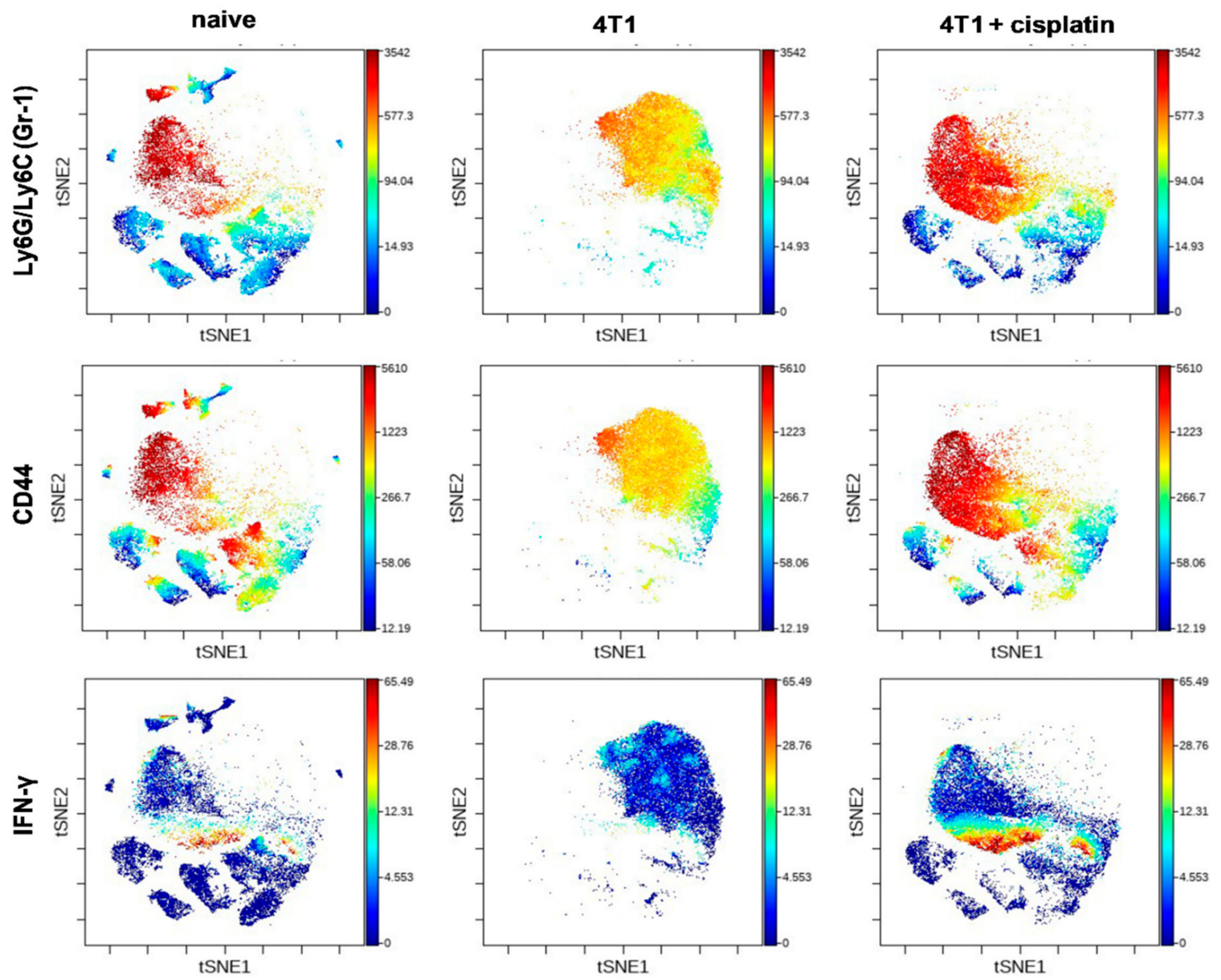

Figure 8. The viSNE plots illustrate the expression intensity of Gr-1, CD44, and IFN- $\gamma$ markers within the clouds of main subsets defined in Figure 7 in the blood samples of naive, 4T1 tumor bearing, and cisplatin treated 4T1 tumorous mice. The coloration is proportional with the expression intensity (blue $=$ low, red $=$ high). The list of the antibodies can be found in Table 1 in the Section 4.5. Representative viSNE plots are shown from the pooled samples of 6 mice per group. The markers of the panel which were not detected or did not showed different expression are not shown.

Quantitation of the populations with characteristic protein expression was performed by manual gating within the CD45+ living singlets of blood-derived leukocytes. The trajectories on the radar plots delineate the characteristic marker profile of peripheral leukocytes of naive, 4T1 tumor bearing, and cisplatin treated tumorous mice (Figure 9). 
A

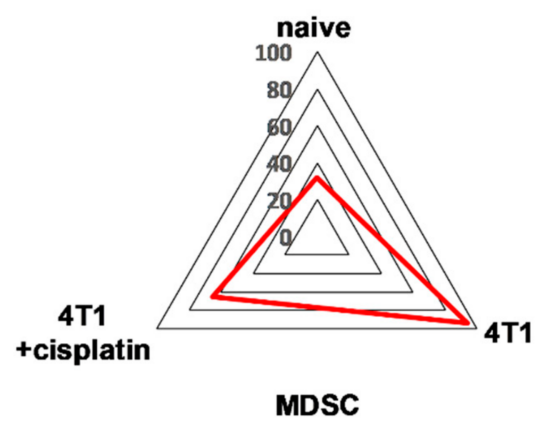

C

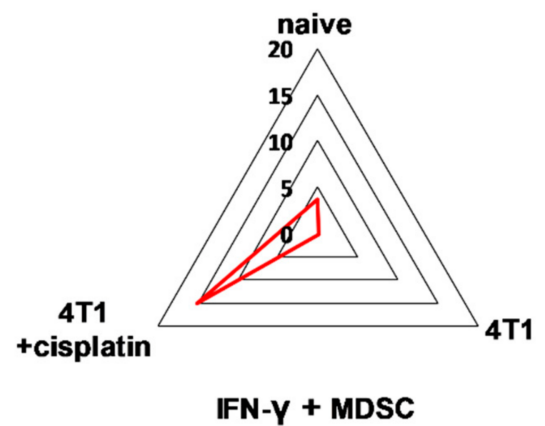

B

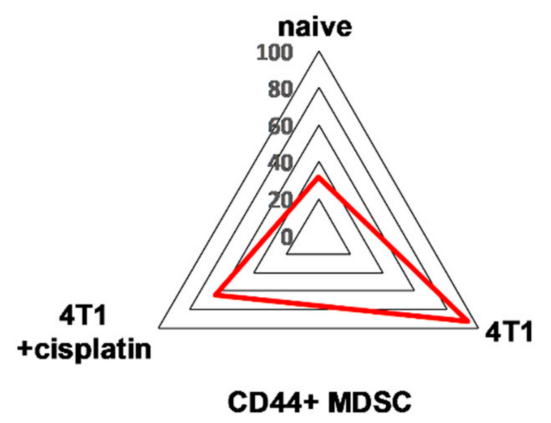

Figure 9. The trajectories on the radar plots delineate the characteristic marker profile of blood-derived leukocytes in naive, $4 \mathrm{~T} 1$ tumor bearing, and cisplatin treated tumorous mice. The accumulation of peripheral (A) CD11b+/Gr-1+ MDSCs and (B) CD44+ MDSCs is a characteristic of 4T1 breast cancer. (C) Due to cisplatin treatment IFN- $\gamma+$ MDSCs were developed at the periphery. The percentage of the given populations is demonstrated on the radar plots within the CD45+ living singlets determined by manual gating in Cytobank. The gating hierarchy is explained in the text. The markers of the panel which were not detected or did not show differential expression are not shown. Representative radar plots are shown from the pooled samples of 6 mice per group as described in Section 4.5.

MDSCs were defined as CD45+/CD3-/CD11+/Gr1+ cells (Figure 9A) and further evaluated for the expression of CD44 (Figure 9B) and IFN- $\gamma$ (Figure 9C). The total MDSCs, CD44+ MDSCs and IFN- $\gamma+$ MDSC represented $92 \%, 93 \%$, and only $0.15 \%$ of CD $45+$ living singlets in the spleen of $4 \mathrm{~T} 1$ advanced tumorous mice, respectively. Administration of cisplatin resulted in the decrease of the percentage of both MDSCs, CD44+ MDSCs to $63 \%$ (naive blood 32\%). Interestingly, IFN- $\gamma$ which is indispensable for antitumor immune response [39], was increased by cisplatin in 15\% of MDSCs (naive $3 \%)$. Sunburst charts represent the immunocomposition of main subsets of the blood detected by single cell mass cytometry in Figure S4B and FlowSOM (Flow data using Self-Organizing Map, [35]) analysis demonstrates the identified clusters, minimum spanning trees (MSTs) of peripheral subsets in Figure S5.

\section{Discussion}

Solid tumors manifest when cancer cells escape from immunosurveillance. During cancer development, malignant cells develop strategies to induce peripheral tolerance and in parallel inflammatory cells change their phenotype to nurse the tumor and suppress anti-tumor effector functions $[36,40]$. Since metastatic breast cancer is the most frequent and deadliest type of cancer among young adult women $[4,5]$, we focused on the $4 \mathrm{~T} 1$ murine breast carcinoma model to study the efficacy of anti-cancer drug candidates. Among chemotherapeutic compounds, cisplatin, a well-known DNA crosslinker, a first line option in human carcinomas was investigated (as a reference drug) in the 4T1 murine metastatic breast carcinoma model. This type of breast carcinoma can be a relevant 
animal model for the human disease because (i) it is orthotopically transplanted into the mammary fat pad, (ii) it grows in immunocompetent mice (BALB/c) and (iii) gives metastasis spontaneously. Here, we studied the immunophenotype of the spleen and blood of mice with advanced cancer and with cisplatin treated cancer compared to naive mice.

We monitored the dose-response curve of cisplatin to $4 \mathrm{~T} 1$ cells in real-time because previous studies described results with endpoint assays [41-43]. The half maximal inhibitory concentration ( $\mathrm{IC}_{50}$ ) values showed time dependence: $36.74 \mu \mathrm{M}$ at $24 \mathrm{~h}, 7.608 \mu \mathrm{M}$ at $48 \mathrm{~h}, 6.962 \mu \mathrm{M}$ at $72 \mathrm{~h}, 4.128 \mu \mathrm{M}$ at $96 \mathrm{~h}$, and $3.995 \mu \mathrm{M}$ at $120 \mathrm{~h}$ (Figure 1 and Figure S1). In order to investigate the alteration of the tumor stroma or the immunophenotype changes during cancer development the 4T1 cells were orthotopically injected into BALB/c mice. Cisplatin reduced the tumor growth, the number of lung metastatic nodules, and splenomegaly (Figure 2). In addition to malignant cells, the alteration of the stroma of solid tumors, namely the activation of cancer-associated fibroblasts has been described as critical determinant of cancer development and survival, and was also confirmed as therapeutic target [2]. It was shown that the expression of FAP prolyl endopeptidase, even on the cell surface or solubilized in the plasma, correlates with the malignancy and cisplatin resistance of carcinomas $[29,44-46]$. Therefore, we have developed an assay to measure the activity of FAP cleaving the Fmoc-Gly-Pro-Cysteic acid-Ile-Gly- $\mathrm{NH}_{2}$ peptide substrate (Figure S2). We could show that cisplatin treatment significantly reduced the FAP activity of the plasma of 4T1 tumor bearing mice (Figure 3).

It has been widely known that the alternative polarization of the immune system, the accumulation of immature myeloid cells (MDSCs) with potent immunosuppression contribute to the cancer development [12,47]. The splenic immunophenotye of mice with advanced cancer showed the emergence of the hyaluronic acid receptor CD44+ and in a smaller extent IL-17A+ MDSCs, the loss of B220+ and CD62L+ B-cells, the loss of CD62L+ CD4+ and CD8+T-cells (Figures 5-7). Myeloid expression of IL-17A in the spleen has been published as a sign of advanced cancer [26]. Cisplatin treatment could restore the splenic immunophenotype downregulating CD44+, IL-17A+ MDSCs presumably because of the smaller tumor burden, on the other hand MDSCs are also sensitive to low dose chemotherapy due to their high proliferative potential [30]. The blood showed the expression of Gr-1+ ${ }^{\mathrm{dim}}$, more immature MDSCs in advanced cancer (Figure 8), which has been reported to suppress T-cell proliferation and IFN- $\gamma$ production [37]. The expression intensity of CD44 on circulating MDSCs was also dim suggesting more immature phenotype (Figure 8), however, the percentage of CD44+MDSCs (irrespective of the CD44 marker intensity) was higher in the blood of mice with advanced cancer (Figure 9). Cisplatin partially reduced the accumulation of $\mathrm{CD} 44+/ \mathrm{CD} 11+/ \mathrm{Gr} 1+$ myeloid cells in the circulation, but changed their phenotype via induction of INF- $\gamma$ production (Figure 9). It has been reported that IFN- $\gamma$ producing immature myeloid cells could exert a potent immune response against sever invasive bacterial infections [48]. Computational tools, unsupervised algorithms were used to summarize our results, such as sunburst population analysis in Figure S4 and the FlowSOM analysis in Figure S5.

The immunomodulatory effect of cisplatin by increasing tumor immunogenicity has been recently published in ovarian cancer [22]. The general overview of chemotherapeutics, especially cisplatin mediated immunomodulation has been reviewed elsewhere [49,50].

To the best of our knowledge our study is the first using single cell mass cytometry to show the immunomodulatory effect of cisplatin in the 4T1 murine model of metastatic triple negative breast cancer via downregulation of immature myeloid cells and upregulation of CD62L+B- and T-cells and IFN- $\gamma+$ peripheral myeloid cells.

\section{Materials and Methods}

\subsection{Real-Time Cell Electronic Sensing (RT-CES) Cytotoxicity Assay}

The 4T1 cells were purchased from the ATCC (American Type Culture Collection, Manassas, VA, USA) and maintained as described previously [10]. Briefly, 4T1 were maintained in Roswell Park 
Memorial Institute 1640 medium (RPMI-1640) with $10 \%$ FCS. The $\mathrm{pH}$ of the cell culture media was controlled to be between 7.2-7.4 prior use. The medium was supplemented with 2 mM GlutaMAX, and $100 \mathrm{U} / \mathrm{mL}$ penicillin, $100 \mu \mathrm{g} / \mathrm{mL}$ streptomycin (Life Technologies, Carlsbad, CA, USA) before use. Cells were passed every three days and placed in a humidified incubator at $37^{\circ} \mathrm{C} 5 \% \mathrm{CO}_{2}$ (Sanyo, Osaka, Japan). The xCelligence real-time cell electronic sensing (RT-CES) cytotoxicity assay (Acea Biosciences, San Diego, CA, USA) was performed as previously described with some modifications $[25,51]$. Briefly, 96-well E-plate (Acea Biosciences) was coated with gelatin solution $(0.2 \%$ in phosphate buffered saline, PBS) for $20 \mathrm{~min}$ at $37^{\circ} \mathrm{C}$, then gelatin was washed twice with PBS solution. Growth media $(50 \mu \mathrm{L})$ was then gently dispensed into each well of the 96-well E-plate for background readings by the RT-CES system prior to addition of $50 \mu \mathrm{L}$ of the cell suspension containing $2 \times 10^{4} 4 \mathrm{~T} 1$ cells. Plates were kept at room temperature in a tissue culture hood for $30 \mathrm{~min}$ prior to insertion into the RT-CES device in the incubator to allow cells to settle. Cell growth was monitored for $48 \mathrm{~h}$ by measurements of electrical impedance every $15 \mathrm{~min}$. Continuous recording of impedance in cells was reflected by cell index value. $48 \mathrm{~h}$ later cells were treated with an increasing concentration $(134 \mathrm{nM}-100 \mu \mathrm{M})$ of cisplatin (Selleckchem, Houston, TX, USA), treatments are demonstrated between 3.704-100 $\mu \mathrm{M}$. Treated and control wells were dynamically monitored over $120 \mathrm{~h}$ by measurements of electrical impedance every $15 \mathrm{~min}$. The raw plate reads for each titration point were normalized relative to the cell index status right before treatment. Each treatment was repeated in 3 wells per plate during the experiments. The half maximal inhibitory concentration $\left(\mathrm{IC}_{50}\right)$ was calculated with relation to untreated control cells ( 1 corresponds to $100 \%$ viability on the y axis), and blank wells containing media without cells. $\mathrm{IC}_{50}$ values (50\% inhibiting concentration) were calculated by GraphPad Prism ${ }^{\circledR}$ (version 5.01, La Jolla, CA, USA).

\subsection{The $4 T 1$ in Vivo Breast Carcinoma Model}

The animal experiments were performed in accordance with animal experimentation and ethics guidelines of the EU (2010/63/EU). Experimental protocols were approved by the responsible governmental agency (National Food Chain Safety Office) in possession of an ethical clearance XXIX./128/2013.

Female Charles River-derivative BALB/c mice (8-10 week old) were purchased from Kobay Ltd., (Ankara, Turkey) and were injected orthotopically with $4 \mathrm{~T} 1$ breast carcinoma cells $\left(1.2 \times 10^{5}\right.$ cells) as described previously [9]. The animals had free access to food and water. Six mice were included into each experimental group. Treatment by cisplatin (Ebewe Pharma, Unterach am Attersee, Austria) was started after 10 days of inoculation and followed in every 5 th day in $5 \mathrm{mg} / \mathrm{kg}$ dose administered intraperitoneally twice on the day of the treatment. The experiments were repeated independently two times under the same conditions, the pooled results have been presented in the paper $(n=12)$. Tumors were evaluated macroscopically by the following parameters: 1 ) incidence of palpable tumors was determined by the daily monitoring of animals in each experimental group; 2 ) tumor size was measured with a precision caliper and calculated according to the formula: $\mathrm{d} 2 \times \mathrm{D} \times 0.5$, where $\mathrm{d}$ and $\mathrm{D}$ are the minor and major diameters, respectively; 3 ) after euthanizing the animals, weights of the excised primary tumors, spleens, and lungs were measured. Spleen and blood were processed freshly in order to isolate leukocytes. Mice showing signs of suffering (lost $15 \%$ of body weight and/or loss of the righting reflex and/or enable to eat, drink) due to (ethical) legislation were sacrificed.

\subsection{Synthesis of Fmoc-Gly-Pro-Cysteic Acid-Ile-Gly-NH$H_{2}$ Peptide}

In order to obtain the target peptide, Fmoc-Gly-Pro-Cysteic acid-Ile-Gly- $\mathrm{NH}_{2}$, first Fmoc-Gly-Pro-Cys-Ile-Gly- $\mathrm{NH}_{2}$ peptide was synthesized (Fmoc, 9-fluorenylmethoxycarbonyl, Avidin Ltd., Szeged, Hungary). Reagents, otherwise not stated, were purchased from Sigma-Aldrich (St. Louis, MI, USA). Fmoc-strategy synthesis was carried out manually in a solid-phase vessel on Rink Amide ChemMatrix resin, the protected Fmoc-amino acids (3 equiv.) were coupled using DCC (dicyclohexylcarbodiimide 3 equiv.) and HOBt (1-hydroxybenzotriazole, 3 equiv.) in DMF 
( $\mathrm{N}, \mathrm{N}$-dimethylformamide) for $2 \mathrm{~h}$ at room temperature. The deprotection of the Fmoc-group was achieved with the treatment of the resin with $5 \%$ piperazine/DMF $(1 \times 5 \mathrm{~min}, 1 \times 20 \mathrm{~min})$. Washings between coupling and deprotection were performed with DMF $(3 \times 1 \mathrm{~min}), \mathrm{MeOH}$ (methanol) $(1 \times 1 \mathrm{~min})$ and DMF $(3 \times 1 \mathrm{~min})$. The completion of the coupling was monitored using the Kaiser test. Following the final coupling, the resin was washed with DMF $(3 \times 1 \mathrm{~min})$ and $\mathrm{MeOH}(3 \times 1 \mathrm{~min})$, and dried under a stream of air. The dry resin was treated with $\mathrm{TFA} / \mathrm{H}_{2} \mathrm{O}$ (trifluoroacetic acid $/ \mathrm{H}_{2} \mathrm{O}, 95: 5$ ) for $3 \mathrm{~h}$ at room temperature. The cleavage mixture was lyophilized, and the pellet was redissolved in $\mathrm{MeOH} / \mathrm{AcN}$ (methanol/acetonitrile, 1:1) for Liquid chromatography-mass spectrometry (LC-MS) analysis (Agilent, Santa Clara, CA, USA). The LC-MS analysis found that Fmoc-Gly-Pro-Cys-Ile-Gly- $\mathrm{NH}_{2}$ was obtained in $90 \%$ purity (linear gradient from $0 \%$ to $100 \% \mathrm{AcN}$ over $30 \mathrm{~min}, \mathrm{t}_{\mathrm{R}}: 21.77 \mathrm{~min}$ ). LC-MS observed $[\mathrm{M}+\mathrm{H}]^{+}$667.2, required $[\mathrm{M}+\mathrm{H}]^{+}$667.8. The obtained Fmoc-Gly-Pro-Cys-Ile-Gly- $\mathrm{NH}_{2}$ was transformed into Fmoc-Gly-Pro-Cysteic acid-Ile-Gly- $\mathrm{NH}_{2}$ peptide with no further purification. It was dissolved in acetone, cooled to $1{ }^{\circ} \mathrm{C}$ in a mixture of ice and water. First $30 \%$ aqueous $\mathrm{H}_{2} \mathrm{O}_{2}$ was added, then $\mathrm{Na}_{2} \mathrm{WO}_{4} \cdot 2 \mathrm{H}_{2} \mathrm{O}$ in catalytic amount. After $3 \mathrm{~h}$, we did not detect the starting material (Fmoc-Gly-Pro-Cys-Ile-Gly- $\mathrm{NH}_{2}$ ), it completely transformed into the desired Fmoc-Gly-Pro-Cysteic acid-Ile-Gly- $\mathrm{NH}_{2}$ peptide. The LC-MS analysis found that Fmoc-Gly-Pro-Cysteic acid-Ile-Gly- $\mathrm{NH}_{2}$ was obtained in $75 \%$ purity (linear gradient from $0 \%$ to $100 \%$ AcN over $\left.30 \mathrm{~min}, \mathrm{t}_{\mathrm{R}}: 16.90 \mathrm{~min}\right)$. LC-MS observed $[\mathrm{M}+\mathrm{H}]^{+}$715.2, required $[\mathrm{M}+\mathrm{H}]^{+} 715.8$. To purify the crude peptide, it was dissolved in $\mathrm{AcN} / \mathrm{MeOH} / \mathrm{H}_{2} \mathrm{O}$, then filtered, using a $0.45 \mu \mathrm{m}$ nylon filter. Gradient elution was used, $70-100 \% \mathrm{AcN}$ in $60 \mathrm{~min}$ at a $3 \mathrm{~mL}$ min- 1 flow rate with detection at $220 \mathrm{~nm}$. Pure fractions were collected and lyophilized to give a fluffy white material.

\subsection{FAP Activity Assay}

Blood from control and tumor bearing (untreated and cisplatin treated) BALB/c mice was drawn $(200 \mu \mathrm{L})$ into EDTA containing tubes (separately from 3 animals from each group). Reagents, otherwise not stated, were purchased from Sigma-Aldrich. Blood samples were centrifuged at 12,000 RPM for $10 \mathrm{~min}$. Supernatant (plasma) was removed and transferred to fresh tubes and were immediately used. Digestion reactions were set up by combining $36 \mu \mathrm{L}$ plasma and $9 \mu \mathrm{L}$ solution of cysteine acid containing peptide solution $(5 \mathrm{mg} / \mathrm{mL})$ for a final peptide concentration of $1 \mathrm{mg} / \mathrm{mL}$. Reactions were incubated at $37^{\circ} \mathrm{C}$ for $60 \mathrm{~min}$. After incubation, $75 \mu \mathrm{L}$ of acetonitrile containing $0.2 \%$ trifluoro-acetic (TFA) acid was added and samples were centrifuged at 12,000 RPM for $5 \mathrm{~min} .80 \mu \mathrm{L}$ of supernatant was removed and transferred to fresh tubes and were stored at $-20^{\circ} \mathrm{C}$ until analysis. Area under the curve (AUC) values of the peptide digestion product 2 were plotted.

\subsection{Mass Cytometry}

Single cell mass cytometry (CyTOF, Fluidigm, San Francisco, CA, USA)) was performed as described previously with some modifications [52]. Briefly, naive, 4T1 breast tumor bearing and cisplatin treated 4T1 tumor bearing mice were euthanized on the 23rd day after 4T1 injection. Spleen and blood were processed freshly. Withdrawal of the blood was carried by cardiac puncture using $50 \mu \mathrm{L}$ EDTA (30 mg/mL) per syringe (Beckton Dickinson, Franklin Lakes, NY, USA). Spleen was smashed on $100 \mu \mathrm{m}$ cell strainer (VWR, Radnoe, PA, USA), washed with PBS and centrifuged at $1400 \mathrm{rpm} 5 \mathrm{~min}$. Blood was centrifuged at $2000 \mathrm{rpm}$ for $10 \mathrm{~min}$, plasma was harvested and stored at $-80^{\circ} \mathrm{C}$. Both the pellet of spleen and blood were resuspended. Red blood cell lysis was carried out by the incubation of cells with $5 \mathrm{~mL}$ ACK $\left(0.155 \mathrm{M} \mathrm{NH}_{4} \mathrm{Cl}, 10 \mathrm{mM} \mathrm{KHCO}_{3}, 0.1 \mathrm{mM} \mathrm{Na}_{2}\right.$ EDTA, pH 7.3, Sigma-Aldrich) solution for $5 \mathrm{~min}$. Samples were loaded on cell strainer $(70 \mu \mathrm{m}$ in pore size, $)$ and washed by $20 \mathrm{~mL}$ PBS. Cells were counted using Bürker chamber and trypan blue viability dye. Three million cells were pooled from six mice per group for mass cytometry (Helios, Fluidigm, San Francisco, CA, USA). The in vivo experiment and CyTOF were repeated twice. Cells viability was determined by cisplatin ( $5 \mu \mathrm{M}$ 195Pt, Fluidigm) staining for $3 \mathrm{~min}$ on ice in $300 \mu \mathrm{L}$ PBS. Sample was diluted by $1500 \mu \mathrm{L}$ Maxpar Cell Staining Buffer (MCSB, Fluidigm) and centrifuged at $350 \mathrm{~g}$ for $5 \mathrm{~min}$. Cells were suspended in 
$50 \mu \mathrm{L}$ MCSB and the antibody mix (Table 1) was added in $50 \mu \mathrm{L}$ (each antibody diluted finally 1:100). Two commercially available antibody panel was combined, the Maxpar ${ }^{\circledR}$ Mouse Sp/LN Phenotyping Panel kit (Fluidigm, cat. numbers 201306) and Maxpar ${ }^{\circledR}$ Mouse Intracellular I Cytokine Panel kit (Fluidigm, cat. number 201310).

Samples after $60 \mathrm{~min}$ incubation at $4{ }^{\circ} \mathrm{C}$, antibodies were washed by $2 \mathrm{~mL}$ MCSB and centrifuged at $300 \mathrm{~g} 5 \mathrm{~min}$, two times. The pellet was suspended in the residual volume. Cells were fixed in $1.6 \%$ formaldehyde (freshly diluted from 16\% Pierce formaldehyde with PBS, Thermo Fisher Scientific, Waltham, MA, USA) and incubated for $10 \mathrm{~min}$ at room temperature. Cells were centrifuged at $800 \mathrm{~g}$ for $5 \mathrm{~min}$. Cell ID DNA intercalator (125 $\mu$ M, 191/193 Iridium, Fluidigm) was added in 1000× dilution in Maxpar Fix and Perm for overnight at $4{ }^{\circ} \mathrm{C}$. Cells for the acquisition were centrifuged at $800 \mathrm{~g}$ for $5 \mathrm{~min}$ then were washed by $2 \mathrm{~mL} \mathrm{MCSB}$ and centrifuged at $800 \mathrm{~g}$ for $5 \mathrm{~min}$. Cells were suspended in $1 \mathrm{~mL}$ PBS (for WB injector) and counted in Bürker-chamber during centrifugation. For the acquisition the concentration of cells was set to $0.5 \times 10^{6} / \mathrm{mL}$ in cell acquisition solution (CAS, Fluidigm) containing 10\% EQ Calibration Beads. Cells were filtered through $30 \mu \mathrm{m}$ Celltrics gravity filter (Sysmex, Görlitz, Germany) and acquired freshly. Mass cytometry data were analyzed in Cytobank (Beckman Coulter, Brea, CA, USA). Single living cells were determined. The viSNE analysis was carried-out (iterations $=1000$, perplexity $=30$, theta $=0.5$ ) on $5 \times 10^{4}$ for the spleen and $2 \times 10^{4}$ for blood of CD45+ living singlets. Reduction of dimensionality was performed by FlowSOM also, by an algorithm creating self-organizing maps during automated clustering in Cytobank [35].

\subsection{Statistical Analysis}

Results are shown as arithmetic mean \pm standard error of the mean (SEM); statistical comparisons were performed by two-tailed Student's t-test as pairwise comparisons as described in the figure legends. In all statistical comparisons, probability " $p$ " was set as the level of significance (set at ${ }^{*} p<0.05,{ }^{* *} p<0.01,{ }^{* * *}, p<0.001$ ). Data were processed and analyzed using Microsoft Excel (Microsoft Office 2016, Redmond, WA, USA), and visualized using GraphPad Prism or Cytobank.

\section{Conclusions}

Our findings showed that cisplatin treatment reduced tumor growth, number of lung metastasis and the splenomegaly of $4 \mathrm{~T} 1$ tumor bearing mice. Cisplatin inhibited the tumor stroma formation, the activation of carcinoma-associated fibroblasts by the diminished proteolytic activity of fibroblast activating protein. Single cell mass cytometry revealed that cisplatin could exert a potent immunomodulatory effect via inhibiting the accumulation of splenic MDSCs in a murine model of metastatic triple negative breast cancer. Emergence of certain myeloid subsets in the spleen, such as CD44+MDSCs and IL-17A+MDSC were associated with advanced cancer, while within the lymphoid subsets, the absence the B220+ B-cells, CD62L+ B-cells, CD62L+CD4+ T-cells, and CD62L+ CD8+ T-cells was shown in the untreated tumor bearing mice. However, cisplatin treatment could restore the splenic immunophenotype similar to naive mice. Peripheral MDSCs in the circulation were not completely eliminated by cisplatin but myeloid-derived IFN- $\gamma$ production was increased. Thus, our study highlights the use of low-dose chemotherapy, such as cisplatin in combination with immunotherapies to treat triple negative breast cancer.

Supplementary Materials: Supplementary Materials can be found at http://www.mdpi.com/1422-0067/21/1/170/s1.

Author Contributions: Conceptualization, L.G.P. and G.J.S.; methodology, J.A.B., L.H.J., A.K.K., P.N., R.A., L.I.N., and G.J.S.; software, J.Á.B.; validation, J.Á.B.; formal analysis, J.Á.B., L.H.J., and G.J.S.; investigation, J.A.B, L.H.J., A.K.K., P.N., R.A., L.I.N., and G.J.S.; resources, L.G.P.; data curation, J.A.B., L.H.J., L.G.P., and G.J.S.; writing—original draft preparation, L.H.J., L.G.P., and G.J.S.; writing—-review and editing, L.H.J., L.G.P., and G.J.S.; visualization, J.Á.B. and G.J.S.; supervision, L.G.P. and G.J.S., project administration, L.G.P.; funding acquisition, L.G.P. All authors have read and agreed to the published version of the manuscript.

Funding: This research was funded by the following grants: GINOP-2.3.2-15-2016-00001 (BRC) by the National Research, Development and Innovation Office, Hungary; and EUREKA Network Program (H2020; E12655 
MITOME) (Avidin Ltd.). Gábor J. Szebeni was supported by János Bolyai Research Scholarship of the Hungarian Academy of Sciences (BO/00139/17/8) and by the UNKP-19-4-SZTE-36 New National Excellence Program of the Ministry for Innovation and Technology.

Conflicts of Interest: The authors declare no conflict of interest.

\section{References}

1. Marx, J. Cancer biology. All in the stroma: cancer's Cosa Nostra. Science 2008, 320, 38-41. [CrossRef]

2. Hanahan, D.; Weinberg, R.A. Hallmarks of cancer: The next generation. Cell 2011, 144, 646-674. [CrossRef]

3. Adams, S.; Gatti-Mays, M.E.; Kalinsky, K.; Korde, L.A.; Sharon, E.; Amiri-Kordestani, L.; Bear, H.; McArthur, H.L.; Frank, E.; Perlmutter, J.; et al. Current Landscape of Immunotherapy in Breast Cancer: A Review. JAMA Oncol. 2019. [CrossRef]

4. Harbeck, N.; Penault-Llorca, F.; Cortes, J.; Gnant, M.; Houssami, N.; Poortmans, P.; Ruddy, K.; Tsang, J.; Cardoso, F. Breast cancer. Nat. Rev. Dis. Primers 2019, 5, 66. [CrossRef] [PubMed]

5. Anders, C.K.; Johnson, R.; Litton, J.; Phillips, M.; Bleyer, A. Breast cancer before age 40 years. Semin. Oncol. 2009, 36, 237-249. [CrossRef] [PubMed]

6. Aslakson, C.J.; Miller, F.R. Selective events in the metastatic process defined by analysis of the sequential dissemination of subpopulations of a mouse mammary tumor. Cancer Res. 1992, 52, 1399-1405. [PubMed]

7. Tao, K.; Fang, M.; Alroy, J.; Sahagian, G.G. Imagable 4T1 model for the study of late stage breast cancer. BMC Cancer 2008, 8, 228. [CrossRef] [PubMed]

8. Lasso, P.; Llano Murcia, M.; Sandoval, T.A.; Uruena, C.; Barreto, A.; Fiorentino, S. Breast Tumor Cells Highly Resistant to Drugs Are Controlled Only by the Immune Response Induced in an Immunocompetent Mouse Model. Integr. Cancer Ther. 2019, 18. [CrossRef]

9. Szebeni, G.J.; Kriston-Pal, E.; Blazso, P.; Katona, R.L.; Novak, J.; Szabo, E.; Czibula, A.; Fajka-Boja, R.; Hegyi, B.; Uher, F.; et al. Identification of galectin-1 as a critical factor in function of mouse mesenchymal stromal cell-mediated tumor promotion. PLoS ONE 2012, 7, e41372. [CrossRef]

10. Szebeni, G.J.; Balog, J.A.; Demjen, A.; Alfoldi, R.; Vegi, V.L.; Feher, L.Z.; Man, I.; Kotogany, E.; Guban, B.; Batar, P.; et al. Imidazo [1,2-b] pyrazole-7-carboxamides Induce Apoptosis in Human Leukemia Cells at Nanomolar Concentrations. Molecules 2018, 23, 2845. [CrossRef]

11. Demjen, A.; Alfoldi, R.; Angyal, A.; Gyuris, M.; Hackler, L., Jr.; Szebeni, G.J.; Wolfling, J.; Puskas, L.G.; Kanizsai, I. Synthesis, cytotoxic characterization, and SAR study of imidazo [1,2-b] pyrazole-7-carboxamides. Arch. Pharm. (Weinheim) 2018, 351. [CrossRef] [PubMed]

12. Szebeni, G.J.; Vizler, C.; Kitajka, K.; Puskas, L.G. Inflammation and Cancer: Extra- and Intracellular Determinants of Tumor-Associated Macrophages as Tumor Promoters. Mediat. Inflamm. 2017, 2017. [CrossRef] [PubMed]

13. Ouzounova, M.; Lee, E.; Piranlioglu, R.; El Andaloussi, A.; Kolhe, R.; Demirci, M.F.; Marasco, D.; Asm, I.; Chadli, A.; Hassan, K.A.; et al. Monocytic and granulocytic myeloid derived suppressor cells differentially regulate spatiotemporal tumour plasticity during metastatic cascade. Nat. Commun. 2017, 8. [CrossRef] [PubMed]

14. Dos Reis, D.C.; Damasceno, K.A.; de Campos, C.B.; Veloso, E.S.; Pegas, G.R.A.; Kraemer, L.R.; Rodrigues, M.A.; Mattos, M.S.; Gomes, D.A.; Campos, P.P.; et al. Versican and Tumor-Associated Macrophages Promotes Tumor Progression and Metastasis in Canine and Murine Models of Breast Carcinoma. Front. Oncol. 2019, 9, 577. [CrossRef]

15. Piranlioglu, R.; Lee, E.; Ouzounova, M.; Bollag, R.J.; Vinyard, A.H.; Arbab, A.S.; Marasco, D.; Guzel, M.; Cowell, J.K.; Thangaraju, M.; et al. Primary tumor-induced immunity eradicates disseminated tumor cells in syngeneic mouse model. Nat. Commun. 2019, 10, 1430. [CrossRef]

16. Li, X.; Singh, K.; Luo, Z.; Mejia-Cordova, M.; Jamalpour, M.; Lindahl, B.; Zhang, G.; Sandler, S.; Welsh, M. Pro-tumoral immune cell alterations in wild type and Shb-deficient mice in response to $4 \mathrm{~T} 1$ breast carcinomas. Oncotarget 2018, 9, 18720-18733. [CrossRef]

17. Kim, K.; Skora, A.D.; Li, Z.; Liu, Q.; Tam, A.J.; Blosser, R.L.; Diaz, L.A., Jr.; Papadopoulos, N.; Kinzler, K.W.; Vogelstein, B.; et al. Eradication of metastatic mouse cancers resistant to immune checkpoint blockade by suppression of myeloid-derived cells. Proc. Natl. Acad. Sci. USA 2014, 111, 11774-11779. [CrossRef]

18. Szebeni, G.J.; Vizler, C.; Nagy, L.I.; Kitajka, K.; Puskas, L.G. Pro-Tumoral Inflammatory Myeloid Cells as Emerging Therapeutic Targets. Int. J. Mol. Sci. 2016, 17, 1958. [CrossRef] 
19. Dasari, S.; Tchounwou, P.B. Cisplatin in cancer therapy: Molecular mechanisms of action. Eur. J. Pharmacol. 2014, 740, 364-378. [CrossRef]

20. Voorwerk, L.; Slagter, M.; Horlings, H.M.; Sikorska, K.; van de Vijver, K.K.; de Maaker, M.; Nederlof, I.; Kluin, R.J.C.; Warren, S.; Ong, S.; et al. Immune induction strategies in metastatic triple-negative breast cancer to enhance the sensitivity to PD-1 blockade: The TONIC trial. Nat. Med. 2019, 25, 920-928. [CrossRef]

21. Wakita, D.; Iwai, T.; Harada, S.; Suzuki, M.; Yamamoto, K.; Sugimoto, M. Cisplatin Augments Antitumor T-Cell Responses Leading to a Potent Therapeutic Effect in Combination With PD-L1 Blockade. Anticancer Res. 2019, 39, 1749-1760. [CrossRef] [PubMed]

22. Grabosch, S.; Bulatovic, M.; Zeng, F.; Ma, T.; Zhang, L.; Ross, M.; Brozick, J.; Fang, Y.; Tseng, G.; Kim, E.; et al. Cisplatin-induced immune modulation in ovarian cancer mouse models with distinct inflammation profiles. Oncogene 2019, 38, 2380-2393. [CrossRef] [PubMed]

23. Lee, J.O.; Kang, M.J.; Byun, W.S.; Kim, S.A.; Seo, I.H.; Han, J.A.; Moon, J.W.; Kim, J.H.; Kim, S.J.; Lee, E.J.; et al. Metformin overcomes resistance to cisplatin in triple-negative breast cancer (TNBC) cells by targeting RAD51. Breast Cancer Res. 2019, 21, 115. [CrossRef] [PubMed]

24. Mohamad, N.E.; Abu, N.; Yeap, S.K.; Alitheen, N.B. Bromelain Enhances the Anti-tumor Effects of Cisplatin on 4T1 Breast Tumor Model In Vivo. Integr. Cancer Ther. 2019, 18. [CrossRef] [PubMed]

25. Ozsvari, B.; Puskas, L.G.; Nagy, L.I.; Kanizsai, I.; Gyuris, M.; Madacsi, R.; Feher, L.Z.; Gero, D.; Szabo, C. A cell-microelectronic sensing technique for the screening of cytoprotective compounds. Int. J. Mol. Med. 2010, 25, 525-530. [CrossRef] [PubMed]

26. Strauss, L.; Sangaletti, S.; Consonni, F.M.; Szebeni, G.; Morlacchi, S.; Totaro, M.G.; Porta, C.; Anselmo, A.; Tartari, S.; Doni, A.; et al. RORC1 Regulates Tumor-Promoting “Emergency" Granulo-Monocytopoiesis. Cancer Cell 2015, 28, 253-269. [CrossRef]

27. Hamson, E.J.; Keane, F.M.; Tholen, S.; Schilling, O.; Gorrell, M.D. Understanding fibroblast activation protein (FAP): Substrates, activities, expression and targeting for cancer therapy. Proteom. Clin. Appl. 2014, 8, 454-463. [CrossRef]

28. Long, X.; Xiong, W.; Zeng, X.; Qi, L.; Cai, Y.; Mo, M.; Jiang, H.; Zhu, B.; Chen, Z.; Li, Y. Cancer-associated fibroblasts promote cisplatin resistance in bladder cancer cells by increasing IGF-1/ERbeta/Bcl-2 signalling. Cell Death Dis. 2019, 10, 375. [CrossRef]

29. Mhawech-Fauceglia, P.; Yan, L.; Sharifian, M.; Ren, X.; Liu, S.; Kim, G.; Gayther, S.A.; Pejovic, T.; Lawrenson, K. Stromal Expression of Fibroblast Activation Protein Alpha (FAP) Predicts Platinum Resistance and Shorter Recurrence in patients with Epithelial Ovarian Cancer. Cancer Microenviron. 2015, 8, 23-31. [CrossRef]

30. Ugel, S.; Peranzoni, E.; Desantis, G.; Chioda, M.; Walter, S.; Weinschenk, T.; Ochando, J.C.; Cabrelle, A.; Mandruzzato, S.; Bronte, V. Immune tolerance to tumor antigens occurs in a specialized environment of the spleen. Cell Rep. 2012, 2, 628-639. [CrossRef]

31. Amir el, A.D.; Davis, K.L.; Tadmor, M.D.; Simonds, E.F.; Levine, J.H.; Bendall, S.C.; Shenfeld, D.K.; Krishnaswamy, S.; Nolan, G.P.; Pe'er, D. viSNE enables visualization of high dimensional single-cell data and reveals phenotypic heterogeneity of leukemia. Nat. Biotechnol. 2013, 31, 545-552. [CrossRef] [PubMed]

32. Rodig, S.J.; Shahsafaei, A.; Li, B.; Dorfman, D.M. The CD45 isoform B220 identifies select subsets of human B cells and B-cell lymphoproliferative disorders. Hum. Pathol. 2005, 36, 51-57. [CrossRef] [PubMed]

33. Driver, D.J.; McHeyzer-Williams, L.J.; Cool, M.; Stetson, D.B.; McHeyzer-Williams, M.G. Development and maintenance of a B220- memory B cell compartment. J. Immunol. 2001, 167, 1393-1405. [CrossRef] [PubMed]

34. Mauri, C.; Menon, M. The expanding family of regulatory B cells. Int. Immunol. 2015, 27, 479-486. [CrossRef]

35. Van Gassen, S.; Callebaut, B.; Van Helden, M.J.; Lambrecht, B.N.; Demeester, P.; Dhaene, T.; Saeys, Y. FlowSOM: Using self-organizing maps for visualization and interpretation of cytometry data. Cytom. A 2015, 87, 636-645. [CrossRef]

36. Gonzalez, H.; Hagerling, C.; Werb, Z. Roles of the immune system in cancer: From tumor initiation to metastatic progression. Genes Dev. 2018, 32, 1267-1284. [CrossRef]

37. Tsiganov, E.N.; Verbina, E.M.; Radaeva, T.V.; Sosunov, V.V.; Kosmiadi, G.A.; Nikitina, I.Y.; Lyadova, I.V. Gr-1dimCD11b+ immature myeloid-derived suppressor cells but not neutrophils are markers of lethal tuberculosis infection in mice. J. Immunol. 2014, 192, 4718-4727. [CrossRef]

38. Sendo, S.; Saegusa, J.; Okano, T.; Takahashi, S.; Akashi, K.; Morinobu, A. CD11b+Gr-1(dim) Tolerogenic Dendritic Cell-Like Cells Are Expanded in Interstitial Lung Disease in SKG Mice. Arthritis Rheumatol. 2017, 69, 2314-2327. [CrossRef] 
39. Lin, C.F.; Lin, C.M.; Lee, K.Y.; Wu, S.Y.; Feng, P.H.; Chen, K.Y.; Chuang, H.C.; Chen, C.L.; Wang, Y.C.; Tseng, P.C.; et al. Escape from IFN-gamma-dependent immunosurveillance in tumorigenesis. J. Biomed. Sci. 2017, 24, 10. [CrossRef]

40. Katoh, H.; Watanabe, M. Myeloid-Derived Suppressor Cells and Therapeutic Strategies in Cancer. Mediat. Inflamm. 2015, 2015. [CrossRef]

41. Yerlikaya, A.; Altikat, S.; Irmak, R.; Cavga, F.Z.; Kocacan, S.A.; Boyaci, I. Effect of bortezomib in combination with cisplatin and 5-fluorouracil on 4T1 breast cancer cells. Mol. Med. Rep. 2013, 8, 277-281. [CrossRef] [PubMed]

42. Paraskar, A.S.; Soni, S.; Chin, K.T.; Chaudhuri, P.; Muto, K.W.; Berkowitz, J.; Handlogten, M.W.; Alves, N.J.; Bilgicer, B.; Dinulescu, D.M.; et al. Harnessing structure-activity relationship to engineer a cisplatin nanoparticle for enhanced antitumor efficacy. Proc. Natl. Acad. Sci. USA 2010, 107, 12435-12440. [CrossRef] [PubMed]

43. Shiassi Arani, F.; Karimzadeh, L.; Ghafoori, S.M.; Nabiuni, M. Antimutagenic and Synergistic Cytotoxic Effect of Cisplatin and Honey Bee Venom on 4T1 Invasive Mammary Carcinoma Cell Line. Adv. Pharmacol. Sci. 2019, 2019. [CrossRef] [PubMed]

44. Liu, R.; Li, H.; Liu, L.; Yu, J.; Ren, X. Fibroblast activation protein: A potential therapeutic target in cancer. Cancer Biol. Ther. 2012, 13, 123-129. [CrossRef] [PubMed]

45. Cremasco, V.; Astarita, J.L.; Grauel, A.L.; Keerthivasan, S.; MacIsaac, K.; Woodruff, M.C.; Wu, M.; Spel, L.; Santoro, S.; Amoozgar, Z.; et al. FAP Delineates Heterogeneous and Functionally Divergent Stromal Cells in Immune-Excluded Breast Tumors. Cancer Immunol. Res. 2018, 6, 1472-1485. [CrossRef] [PubMed]

46. Sandberg, T.P.; Stuart, M.; Oosting, J.; Tollenaar, R.; Sier, C.F.M.; Mesker, W.E. Increased expression of cancer-associated fibroblast markers at the invasive front and its association with tumor-stroma ratio in colorectal cancer. BMC Cancer 2019, 19, 284. [CrossRef] [PubMed]

47. Ostrand-Rosenberg, S.; Fenselau, C. Myeloid-Derived Suppressor Cells: Immune-Suppressive Cells That Impair Antitumor Immunity and Are Sculpted by Their Environment. J. Immunol. 2018, 200, 422-431. [CrossRef]

48. Matsumura, T.; Ato, M.; Ikebe, T.; Ohnishi, M.; Watanabe, H.; Kobayashi, K. Interferon-gamma-producing immature myeloid cells confer protection against severe invasive group A Streptococcus infections. Nat. Commun. 2012, 3, 678. [CrossRef]

49. Kersten, K.; Salvagno, C.; de Visser, K.E. Exploiting the Immunomodulatory Properties of Chemotherapeutic Drugs to Improve the Success of Cancer Immunotherapy. Front. Immunol. 2015, 6, 516. [CrossRef]

50. De Biasi, A.R.; Villena-Vargas, J.; Adusumilli, P.S. Cisplatin-induced antitumor immunomodulation: A review of preclinical and clinical evidence. Clin. Cancer Res. 2014, 20, 5384-5391. [CrossRef]

51. Man, I.; Szebeni, G.J.; Plangar, I.; Szabo, E.R.; Tokes, T.; Szabo, Z.; Nagy, Z.; Fekete, G.; Fajka-Boja, R.; Puskas, L.G.; et al. Novel real-time cell analysis platform for the dynamic monitoring of ionizing radiation effects on human tumor cell lines and primary fibroblasts. Mol. Med. Rep. 2015, 12, 4610-4619. [CrossRef] [PubMed]

52. Alfoldi, R.; Balog, J.A.; Farago, N.; Halmai, M.; Kotogany, E.; Neuperger, P.; Nagy, L.I.; Feher, L.Z.; Szebeni, G.J.; Puskas, L.G. Single Cell Mass Cytometry of Non-Small Cell Lung Cancer Cells Reveals Complexity of In vivo And Three-Dimensional Models over the Petri-dish. Cells 2019, 8, 1903. [CrossRef] [PubMed]

(C) 2019 by the authors. Licensee MDPI, Basel, Switzerland. This article is an open access article distributed under the terms and conditions of the Creative Commons Attribution (CC BY) license (http://creativecommons.org/licenses/by/4.0/). 